\title{
体外循環中の $\mathrm{PGE}_{1}$ の使用経験
}

\author{
市立旭川病院 胸部外科人工心肺係
}

黒田広

市立旭川病院 胸部外科

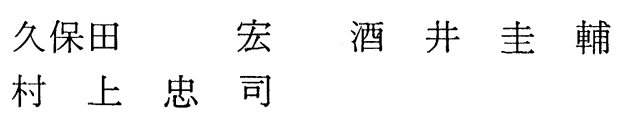

\section{はじめに}

われわれは, Prostaglandin $\mathrm{E}_{1}$ (以下 $\mathrm{PGE}_{1}$ と 呼ぶ）の作用である. 未梢血管拡張作用, 血小板 粘着凝集抑制作用に着目し，体外循環中に $\mathrm{PGE}_{1}$ を使用した。 今回, $\mathrm{PGE}_{1}$ を使用した体外循環中 の循環動態, 及び, 血小板数の変動などについて 若干の知見を得たのでこれを述べる。

\section{対象症例亡方法 （表 1, 表 2)}

過去 1 年間に市立旭川病院で開心術を受けた先 天性心疾患のなかで，体外循環中に $\mathrm{PGE}_{1}$ を使用 した 9 例の $\mathrm{PGE}_{1}$ 群, 体外循環中に血管拡張剂を 使用しなかった 9 例の control 群に分け, 体外循 環中の循環動態, 及び血小板動態について観察し

表 1 PGE 使用症例 PGE，群

\begin{tabular}{|c|c|c|c|c|c|c|}
\hline \multirow{2}{*}{ 症例 } & \multirow{2}{*}{$\begin{array}{l}\text { 年令 } \\
(才)\end{array}$} & \multirow{2}{*}{$\begin{array}{l}\text { 体重 } \\
(\mathrm{kg})\end{array}$} & \multirow{2}{*}{ 疾患名 } & \multirow{2}{*}{$\begin{array}{l}\text { 体外循瓄 } \\
\text { 時間(分) }\end{array}$} & \multicolumn{2}{|c|}{ 潅流量 } \\
\hline & & & & & $\ell / m$ & $\mathrm{ml} / \mathrm{kg}$ \\
\hline 1 & 36 & 68.5 & A S D & 59 & 2.66 & 71.5 \\
\hline 2 & 32 & 54.5 & $A S D$ & 34 & 2.87 & 78.9 \\
\hline 3 & 6 & 20.6 & A S D & 39 & 2.98 & 121.4 \\
\hline 4 & 16 & 38.5 & A S & 70 & 2.79 & 88.3 \\
\hline 5 & 8 & 23. 6 & $V S D+P S$ & 54 & 2.39 & 95.3 \\
\hline 6 & 12 & 31.0 & A S D & 58 & 1.97 & 72.6 \\
\hline 7 & 7 & 19.0 & A S D & 33 & 2.81 & 142.1 \\
\hline 8 & 6 & 20.8 & ASD & 46 & 2.65 & 108.2 \\
\hline 9 & 1 & 10.2 & V S D & 76 & 2.33 & 137.3 \\
\hline
\end{tabular}

た。

$\mathrm{PGE}_{1}$ 群の症例は, $\mathrm{ASD} 6$ 例, VSD 及び VSD $+\mathrm{PS}$ が 1 例, 先天性の AS が 1 例で, 軽症例が 多かった。

Control 群では, ASD 2 例, VSD+PS 2 例, $\mathrm{VSD}+\mathrm{pH} 3$ 例, PS, ASD, ASD+PAPVC が各 1 例であった。体外循環時間をみると, $\mathrm{PGE}_{1}$ 群 は平均52.1分, Control 群は平均 62.5 分と Control 群の方が若干長かった。 また, 体外循環中の灌流 量は, 灌流指数で $\mathrm{PGE}_{1}$ 群, 平均 $2.6 \mathrm{l} / \mathrm{m}^{2} / \mathrm{min}$, Control 群, 平均 $2.7 \mathrm{l} / \mathrm{m}^{2} / \mathrm{min}$ と, これも若干 Control 群の方が多かった. 人工心肺は気泡型 （JMS，LH 肺）と，ローラーポンプを用い, 人工 肺内充填には，新鮮へパリン血 800〜 1, $200 \mathrm{ml}$, ラクテートリンゲル液, $20 \%$ マ

表 2 対照群症例

\section{Control 群}

\begin{tabular}{|c|c|c|c|c|c|c|}
\hline & 年令 & 体重 & 在串名 & 体外循嫧 & & \\
\hline & 才 & $\mathrm{kg}$ & F䍐 & 時間 分 & $\ell \mathrm{m}$ & $\mathrm{ml} \mathrm{kg}$ \\
\hline 1 & 4 & 17.0 & $V S D+P S$ & 73 & 2.68 & 111.8 \\
\hline 2 & 4 & 18.0 & $V S D+P S$ & 57 & 2.63 & 102.2 \\
\hline 3 & 30 & 43.7 & AS D & 35 & 2.96 & 96.1 \\
\hline 4 & 2 & 12.8 & $V S D+P H$ & 62 & 2.88 & 148.9 \\
\hline 5 & 3 & 11.0 & $V S D+P H$ & 46 & 2.79 & 172.7 \\
\hline 6 & 7 & 29.5 & PS & 51 & 1.94 & 64.4 \\
\hline 7 & 37 & 45.1 & ASD & 69 & 2.75 & 86.5 \\
\hline 8 & 10 & 33.0 & ASD + PAPVC & 87 & 2.95 & 100.0 \\
\hline 9 & 3 & 13.8 & $V S D+P H$ & 83 & 2.89 & 159.4 \\
\hline
\end{tabular}


$\mathrm{kg}$ で，希釈率約 25\%にした。体外循環法は， $\mathrm{PGE}_{1}$ 群, Control 群, 同じ方法で行なった. $\mathrm{PGE}_{1}$ の投与方法は，体外循環開始之同時に人工 肺内にマイクロドロップで 1 滴 $1 \mathrm{ng} / \mathrm{kg}$ になるよ うな濃度にし, IVAC 5,700 で 30 滴，すなわち $30 \mathrm{ng} / \mathrm{kg} / \mathrm{min}$ を点滴投与した。

\section{測定項目と方法は次の通りである.}

動静脈圧は, 体外循環前, 体外循環開始15分, 30 分, 45 分, 体外循環終了時, ICU 入室時, そ れに術後第 1 , 第 3 , 第 7 病日の午前 9 時に測定 され，体外循環前を 100 とした相対值の変動を 見た。

尿量は，体外循環中，及び ICU 入室から同日 の午後 10 時までの量, 午後 10 時から翌日の午後 10時までを術後第 1 病日として, $\mathrm{ml} / \mathrm{kg} / \mathrm{h}$ で表わ した.

体外循環中の動静脈血酸素較差は，体外循環開 始15分，30分，45分に測定した。

血小板数は, 体外循環前, または術前, 体外循 環開始15分，30分，45分，体外循環終了時, ICU 入室時, そして術後第 1 , 第 3 , 第 7 病日の午前 9 時に測定され, 血液希釈の関係から, 血小板数 をへマトクリット值で割ったものを血小板 index とし，体外循環前を100 とした相対值の変動をみ
た。

溶血は，分時溶血量で示した。

術後出血量は，抜管までの量を測定し， $\mathrm{ml} / \mathrm{kg}$ で示した。

また, 統計学的処理には, $\mathrm{t}$ 検定を行ない, 判 定は $\mathrm{P}<0.05$ 以下を有意とした.

\section{結 果}

動脈圧の変動は, 図 1 の通りであり, 両群と も, 体外循環開始と同時に下降したが，体外循環 中は, $\mathrm{PGE}_{1}$ 群の方が Control 群より下降し, ICU 入室時には $\mathrm{PGE}_{1}$ 群が Control 群よりも上 昇傾向を示したが, 統計学的には有意の差はなか った。

尿量（図 2) をみると，体外循環中では， $\mathrm{PGE}_{1}$ 群より Control 群が多い傾向を示した. Control 群は, 最低 $2.3 \mathrm{ml} / \mathrm{kg} / \mathrm{h}$, 最高 $31.4 \mathrm{ml} / \mathrm{kg} / \mathrm{h}$ と バラッキが大きく， $\mathrm{PGE}_{1}$ 群では安定した尿量を 得たが，しかし，有意の差はなかったＩCU 入室 日尿量は, $\mathrm{PGE}_{1}$ 群が多い傾向を示したが，術後 第 1 病日では，ほとんど差はなかった。

体外循環中の動静脈血酸素較差（図 3) をみる と, $\mathrm{PGE}_{1}$ 群, Control 群に注涪同様で差はなか った.

血小板数の変動（図 4）をみると，体外循環開

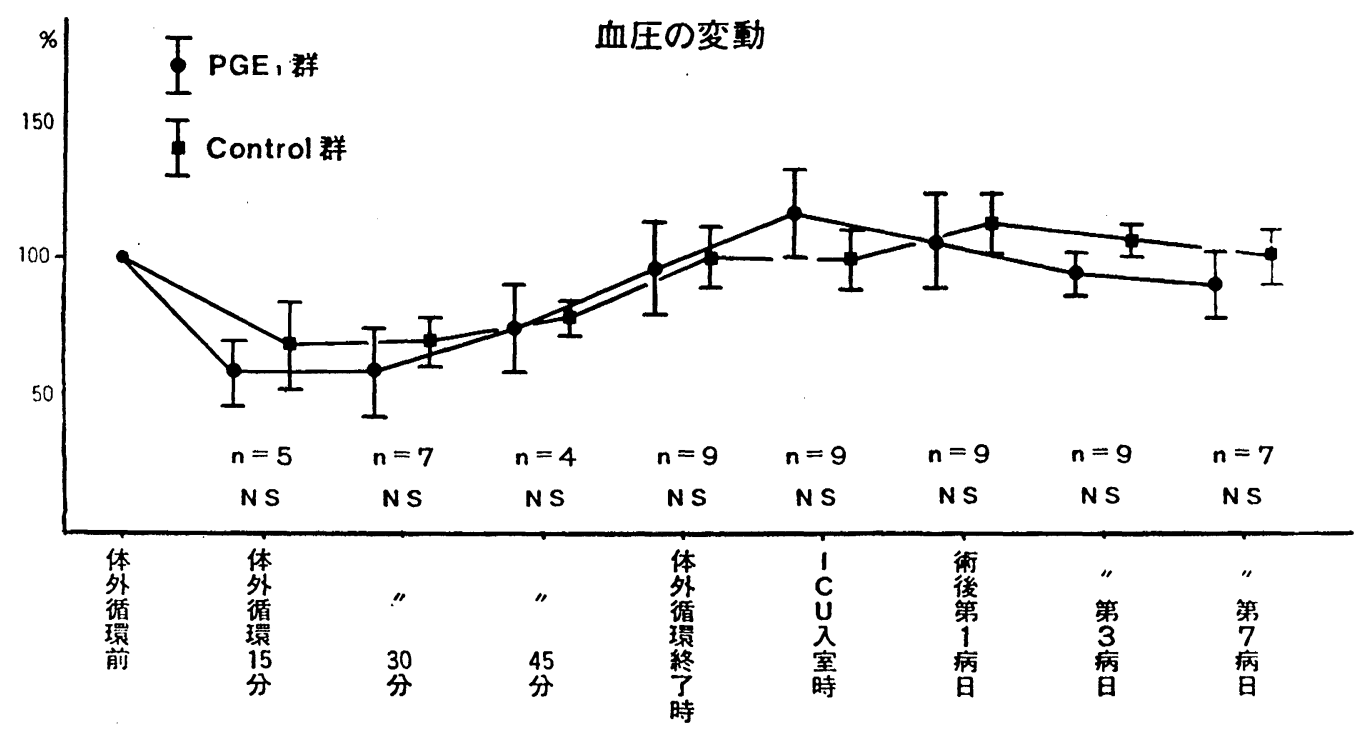

図 1 血圧の変動 
始とともに両群とも下降を示したが, ICU 入室時 では, $\mathrm{PGE}_{1}$ 群の方が, Control 群に比して高く, それ以後は両群とも下降し, 術後第 7 病日には, 体外循環前値に戻っていた。

体外循環中の 分時溶血量（図 5)をみる, $\mathrm{PGE}_{1}$ 群平均 $0.71 \pm 0.32 \mathrm{mg} / \mathrm{d} l / \mathrm{min}$, Control 群

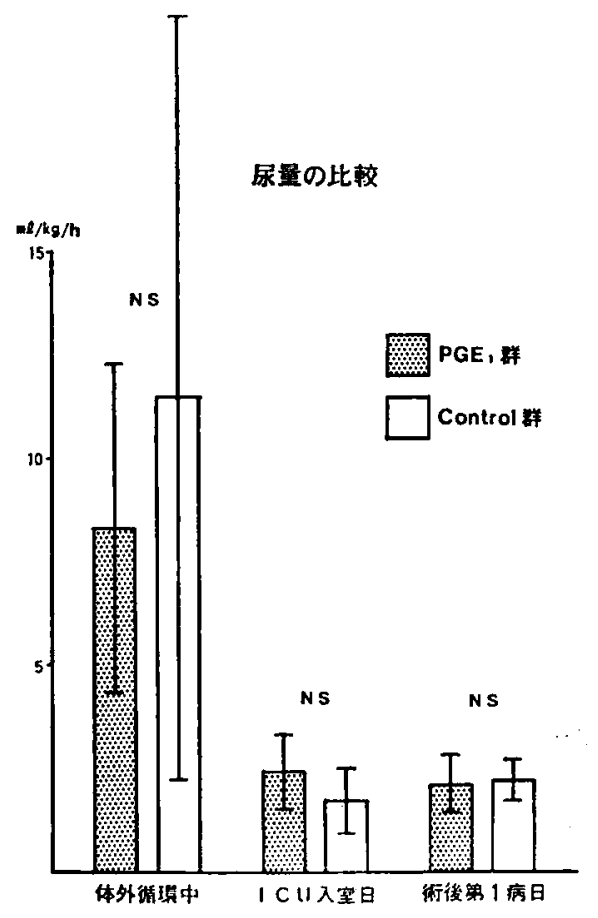

図 2 尿量の比較
のそれは, 平均 $0.92 \pm 0.49 \mathrm{mg} / \mathrm{d} l / \mathrm{min}$ と $\mathrm{PGE}_{1}$ 群の方が低い傾向を示したが統計学的に有意の差 はなかった。

術後出血量（図 6) をみると，PGE 1 群，平均 $14.4 \pm 2.9 \mathrm{ml} / \mathrm{kg}$, Control 群, 平均 $15.5 \pm 5.7$ $\mathrm{ml} / \mathrm{kg}$ と，わずかに $\mathrm{PGE}_{1}$ 群が少なかったが有意 の差はなかった。

\section{総括（考按）}

以上われわれは， $\mathrm{PGE}_{1}$ の末梢血管払張作

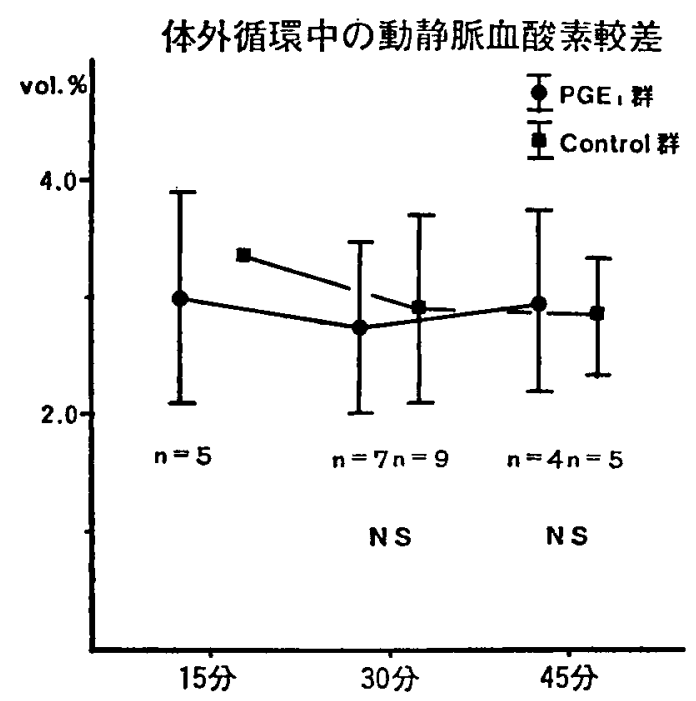

図 3 体外㨁環中の動静脈血酸素較差

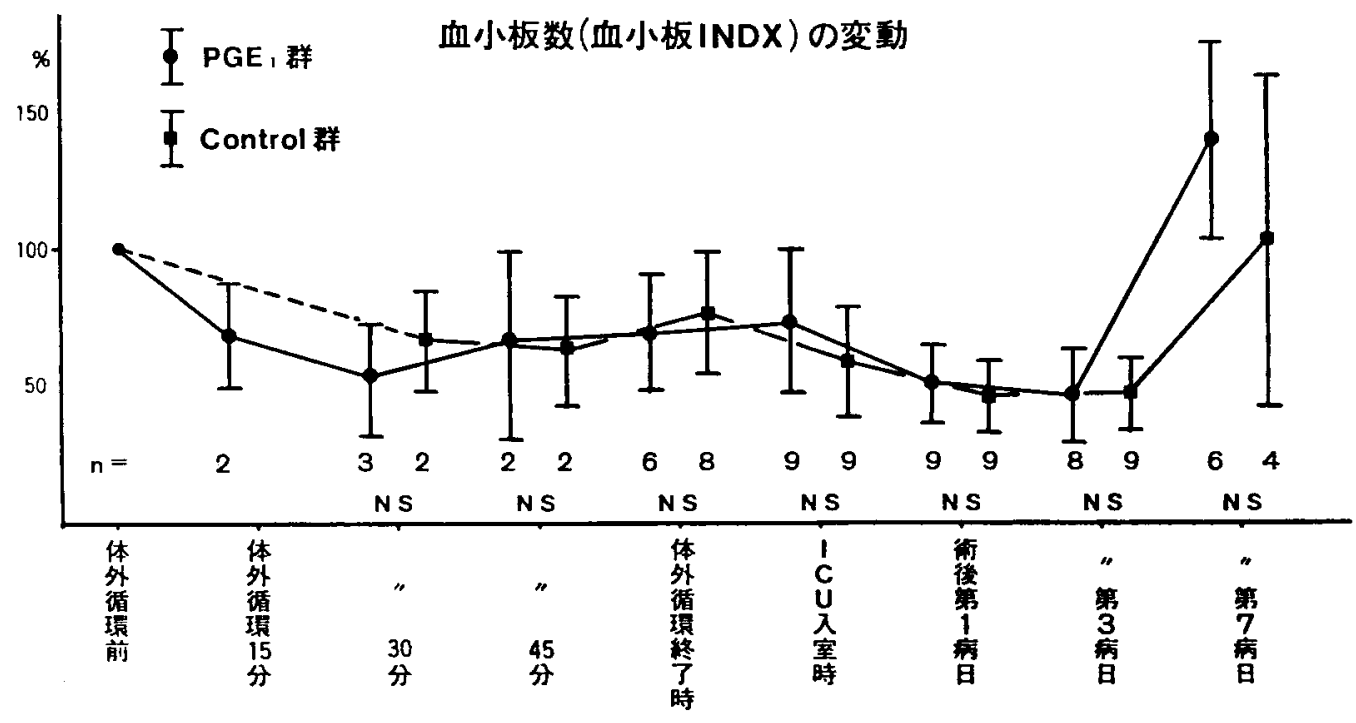

图 4 血小板数の变動 
用, 及び血小板粘着凝集抑制作用に着目し，体外 循環中の末梢循環の改善, 血小板保護を目的とし て，体外循環中に $\mathrm{PGE}_{1}$ 投与を行なって来た. $\mathrm{PGE}_{1}$ を開心術に使用した報告はあまりなく，投 与方法, 及び投与量については, 未だ決定されて いない，われわれの投与方法は, 体外循環が開始 されると, 血圧の initial drop があり, 極端な降 下にならないように, 体外循環開始と同時に点滴 投与し, 開始前から充媜液に添加する方法をとら なかった。 また，体外循環中の動脈圧を平均で $60 \mathrm{mmHg}$ 以上保つょう, $\mathrm{PGE}_{1}$ の点滴投与量を $30 \mathrm{ng} / \mathrm{kg} / \mathrm{min}$ とした。しかし, 同様の投与方法 で行なったにもかかわらず，血圧が体外循環前の 33\%に下降した症例や，83\%とあまり下降しなか った症例もあり, $\mathrm{PGE}_{1}$ の個人による感受性の違 いもあり，これらを考慮しない投与方法に問題が あるものと考えられた。体外循環中の血圧の変動 をみると, わずかに $\mathrm{PGE}_{1}$ 群の方が低く, 終了時 にはほとんど差がなかった。しかし，体外循環を 終了する場合, 自己の血圧が $80 \mathrm{mmHg}$ 以上にな ると体外循環を中止するが， $\mathrm{PGE}_{1}$ 群では, 血圧 を $80 \mathrm{mmHg}$ 以上出すためには, 相当量の血液を 過送血しなければならず, 人工肺内の血液量が少 なくなり, 体外循環を担当する者には, 操作が非

\section{分時溶血毁の比較}

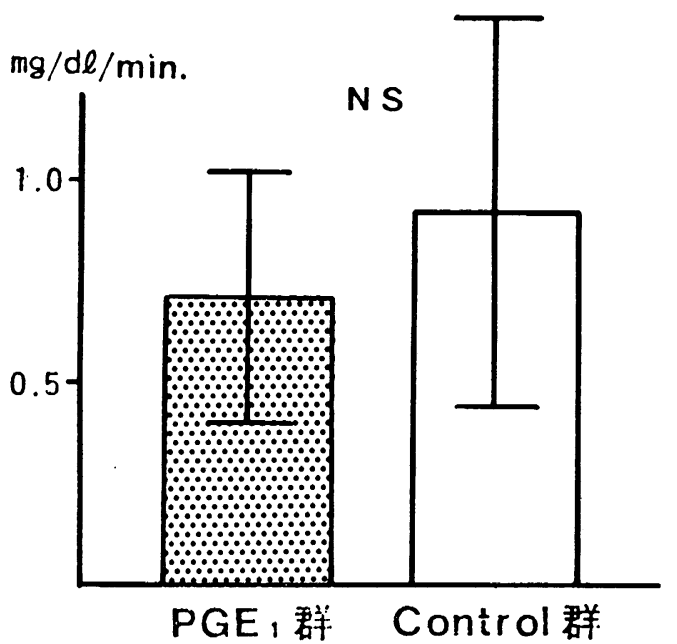

図 5 分時溶血量の比較
常にむつがかった。 また, $\mathrm{PGE}_{1}$ 群では, 体外 循環終了後の血圧が一過性に非常に高くなり, ICU 入室時まで続いた。これは, 体外循環終了時 に, 相当量の血液が体内に入り, ボリューム過剩 となったためと, この時点では $\mathrm{PGE}_{1}$ の点滴が終 って扣り，その末梢血管拡張作用がなくなってい るためと考学られた。尿量の比較では， $\mathrm{PGE}_{1}$ 群 が Control 群より少なかったが，比較的安定した 利尿が得られ，ICU 入室日に尿量が多かった事 は, $\mathrm{PGE}_{1}$ 群が一過性のボリューム過剰となり, それらが ICU で排尿されたものと考えられた。

血小板数の変動をみると, 両群に有意の差はな く，血小板保護作用を得るためには， $\mathrm{PGE}_{1}$ の量 が少なかったものと考光られた。しかし溶血をみ ると, $\mathrm{PGE}_{1}$ 群の方が Control 群より分時溶血量 が少ない傾向を示したが，例数が少なく，今後の 検討を待たなければならない。

\section{術後総出血量の比較}

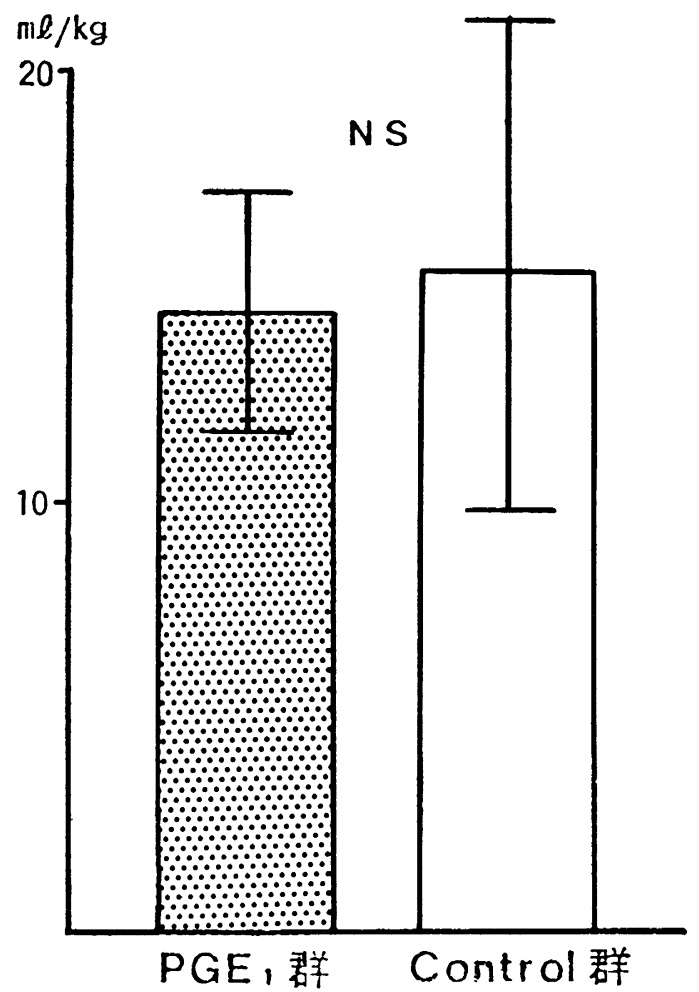

図 6 術後総出血量の比較 


\section{おわりに}

体外循環中に $\mathrm{PGE}_{1}$ を使用し, 体外循環中の循 環動態, 及び血小板動態について観察したが, $\mathrm{PGE}_{1}$ 群, Control 群の両群に有意の 差はなかっ た。これは，われわれの $\mathrm{PGE}_{1}$ 投与量が， $30 \mathrm{ng} /$ $\mathrm{kg} / \mathrm{min}$ だったので, $\mathrm{PGE}_{1}$ 使用に期待する体外 循環中の末梢循環の改善, 血小板保護の維持を得 るためには，もら少し $\mathrm{PGE}_{1}$ の投与量を増加させ る必要があると考光る，今後，更に，体外循環中 の循環動態, 血小板保護の面から満足し得る投与 方法, 投与量を決定すべく検討を続けたい。
参考文献

1) 安斎徹男, 他: $\mathrm{PGE}_{1}$ の臨床, 人工心肺, 現代医 療, 12: 971, 1980.

2) 南川 紀, 他：体外循環時に抢ける Prostaglandin $\mathrm{E}_{1}$ の血行動態に及ぼす影響，現代医療，12: 1009, 1980.

3) Horace R. Trumbull, M.D., et al.: A Comparison of the Effects of Membrane and Bubble Oxygenators on Platelet Counts and Platelet Size in Elective Cardiac Operations. The Annals of Thoracic Surgery, 30: 52, 1980.

4) 安斎徹男, 他：体外循環中の Prostaglandin $E_{1}$ 投与の問題点, 胸部外科, $33: 672,1980$.

5）桜井達夫, 他 : Prostaglandin $\mathrm{E}_{1}$ の体外循環への 応用, 人工臓器, 8: $741,1979$. 